\title{
Legal Parameters to Medical, Ethical and Professional Responsibilities: Are Doctors Appropriately Categorised as Fiduciaries
}

\author{
Scott Guy, B.A., L.L.B., Barbara Ann Hocking*, B.A., L.L.B., L.L.M., PhD, \\ and Stewart Muirhead, L.L.B. (Hons.)
}

\section{INTRODUCTION}

The fundamental principles of medical negligence may be constant but the nature of these incidents is perpetually evolving. Across the common law world there has been a largely judicially imposed rising standard of care expected of the medical practitioner. This paper attempts to outline the various legal requirements and the duty owed by the medical practitioner as articulated by law. It focuses on the new issues facing the medical profession and asks whether a more flexible approach, one observed most particularly in the Canadian context, and one drawing on the concept of fiduciary obligation, might create appropriate legal boundaries to deal with those issues.

Taking account of the so-called 'litigation crisis' in Australia (1), our analysis examines the doctrine of fiduciary duties, as it is presently understood, and asks whether it can be developed to provide adequate legal boundaries to the professional and ethical conduct of psychiatrists in particular. Special attention is paid to the recent Australian decision of $B-v$-Marinovich (2), and the approach taken by the court in seeking to define a fiduciary relationship between doctor and patient.

A review of comparative jurisdictions is further undertaken to support the argument that fiduciary duties can be expanded to create new standards in the context of medical negligence. By way of contrast, the paper then compares the ethical considerations arising in the

* To whom correspondence should be addressed: Barbara Ann Hocking, School of Justice Studies, Faculty of Law, Queensland University of Technology Faculty of Law, Brisbane, Queensland, Australia, 4059; Email: b.hocking@qut.edu.au legal profession in the context of their insurance arrangements, and examines the approach taken by the courts in defining those duties. The comparison is undertaken to demonstrate the court's ability to formulate the principle governing the fiduciary obligations of professionals.

\section{FIDUCIARY DUTIES}

In order to establish negligence or "fault" on the part of a medical practitioner, a fiduciary or "special" relationship is required to be present between doctor and patient. English law (3) does not appear to recognise the existence of a fiduciary relationship between doctor and patient in the same terms, for example, as one that exists between a solicitor and client. However, Canadian law (4) does acknowledge the existence of a fiduciary relationship between doctor and patient, as indeed, Canadian law has more generously accommodated the fiduciary concept in other areas of law such as indigenous rights (5). In Australia (6), duties of a fiduciary nature may be imposed on a doctor, but they are confined and do not cover the entire doctor/patient relationship. Before examining whether a fiduciary relationship exists, the first step is to ascertain the nature of a fiduciary relationship.

\section{What is a fiduciary?}

Fiduciary relationships are referred to as relationships of trust and confidence and typically encompass the trustee/beneficiary, principle/agent, solicitor/client, employer/employee and company/director relationships. 
In the leading High Court decision of Breen $v$. Williams (7), it was held that while certain elements of the doctorpatient relationship were fiduciary in nature, in essence, the relationship was contractual in character, where the medical practitioner undertakes to treat and advise the patient and to use reasonable care in doing so (8).

\section{Defining the relationship of fidiciary}

There are three principles which indicate the existence of a fiduciary relationship. The first principle is that of trust and confidence. This principle reflects the fact that there may be imbalances or inequalities of power in a relationship and therefore, as a matter of public policy, the law seeks to impose protective measures that are not ordinarily imposed (9).

A further aspect of a fiduciary relationship is that one party voluntarily undertakes to act on behalf of another party. The doctor/patient relationship satisfies this requirement because "the patient is putting his health and his life in the doctor's hands" (10). The ordinary meaning of "voluntary undertaking" means an undertaking to act in the interests of another, which would imply that one party has consented to assume the role of a fiduciary. This consent would appear to be implied in the "doctor-patient" relationship because the patient has a so-called "special vulnerability". In Breen $-v$-Williams (11) it was considered that there was little difference between a relationship where there was a "voluntary undertaking" and one in which there was a "special vulnerability" .

As well as a "voluntary undertaking" a further aspect of a fiduciary relationship is that the relationship is often one that is based on an unequal distribution of power. Because of the imbalance of power that is inherent in the doctor/patient association, this relationship can give rise to exploitation, which warrants protection in the form of an imposition of a fiduciary duty (12). It has been argued that the principle of "unequal distribution of power" cuts right to the heart of the fiduciary concept in an attempt to identify exactly what it is that makes the fiduciary special (13).

\section{The scope of the fiduciary duty}

The scope of the fiduciary duty is often determined by the nature of the fiduciary relationship, or the subject matter over which the fiduciary obligations extend (14). In Canada, where the concept has been most widely employed, fiduciary duties are not confined to the exercise of power, which can affect the legal interests of the beneficiary, but can extend to the beneficiary's "human or personal interest" (15). These interests are currently outside the protection of the law relating to the conceptualisation of the fiduciary duty in Australia.
Like the solicitor, the doctor has to provide certainty for problems that may be uncertain, and both professions must provide a high standard of professional performance. The provision of legal advice to a client is akin to the exercise by a doctor of an independent medical judgment on the patient's behalf be it making a diagnosis, recommending treatment or implying that no treatment is necessary. Clients entrust solicitors with confidential information, and the position with the patient is no different. It is therefore difficult to see why the scope of the fiduciary duty owed by a doctor to a patient is restricted to the beneficiary's legal interests, but does not extend to personal interests. The solicitor's fiduciary obligations are based very much on the considerations outlined above. In $R e$ Gibson (16), the court held that the lawyer stood in a fiduciary relationship with the client and "should exercise professional judgement solely for the benefit of the client" (17). Considerations of confidence, vulnerability and the obligation that the lawyer must act in the best interests of the client are all underpinning factors giving rise to the fiduciary duty not only to legal matters but to personal matters as well.

These principles represent the recognised basis upon which fiduciary responsibilities exist. The question remains as to whether doctors should be categorised as fiduciaries. On the one hand, it could be argued that the doctor is not an appropriate candidate for fiduciary liability because there is no inequality of power between the doctor and patient. The only power the doctor is likely to receive is from acts of consent for the purpose of diagnosis and treatment.

However, on the other hand, it might be considered that with doctors' specialised training and knowledge, such medical practitioners are therefore at a particular advantage in the relationship. Yet, while an imbalance of power may exist, a patient does have the right of veto and can withdraw consent at any time. This argument would appear to be insufficient to negate the imposition of a fiduciary duty on a doctor. Support for this contention can be gained from McLachlin $\mathrm{J}$ in the Canadian decision of Norberg - $v$ - Wynrib (18) who, when questioning whether a fiduciary relationship existed between a doctor and patient (19), observed that the medical practitioner, Dr Wynrib, was in a position of power and could exercise that power in a way that affected the interests of the patient, Ms Norberg. This position of power was accentuated by the fact that Ms Norberg was addicted to prescription drugs. Dr Wynrib:

had the power to advise her, to treat her, to give her the drug or to refuse her the drug. He could unilaterally exercise that power or discretion in a way that affected her interests and her status 
as a patient rendered her vulnerable and at his mercy, particularly in the light of her addiction (20).

So, all the classic characteristics of a fiduciary relationship were held to be present.

It would appear then that a fiduciary relationship is presumed to exist between the doctor and patient. In the Australian case of $B-v$-Marinovich (21), for example, Riley $J$ highlighted the existence of a fiduciary relationship between the psychiatrist and patient and the duty of care owed by the psychiatrist as a result of this relationship.

\section{THE DUTY AND STANDARD OF CARE}

Once a fiduciary relationship has been established between doctor and patient, the law will impose on the medical practitioner a duty to exercise reasonable care and skill in the provision of professional advice and treatment (22). This duty covers all of the ways in which a doctor is called upon to exercise his or her skill and judgment (23). The duty will extend to the examination, diagnosis and treatment of the patient and the provision of information in an appropriate case (24).

There have been two diverging approaches to evaluating whether a medical practitioner has fulfilled the appropriate duty or, more particularly, standard of care. The first approach was established in the leading case of Bolam - v- Friern Hospital Management Committee (25). According to the Bolam principle, so long as the conduct of the medical practitioner conformed to accepted medical practice then he or she could not have been considered to be negligent. The Court should not impose its own standard of care in preference to that of accepted medical opinion. As the House of Lords held in Bolam (26), "in short the law imposes the duty of care; but the standard of care is a matter of medical judgment."

However, later cases have tended to reject this view. The appropriate standard of care, which is to be exercised by the medical practitioner, is one that is to be decided, independently, by the Court and not be reference to medical opinion. For example, the United States Supreme Court has held that it is the responsibility of the Court to decide if the medical practitioner has fulfilled his or her duty to warn patients of the risks when undergoing medical treatment (27). A similar position has been adopted in Canada where it is the Court, and not the medical profession, that decides the extent to which the risks involved in medical treatment have been adequately disclosed (28).

The High Court has followed this approach in the leading decision of Rogers - $v$-Whitaker (29). Mason CJ held that when deciding whether a doctor has been negligent, reference needed to be made to legal principles, as well as accepted professional practice. Thus, it was the responsibility of jurors and the Court to use their own common sense when determining if a medical practitioner had been negligent, as opposed to relying on a medical "expert" (30).

This latter method enables the courts to take a more interventionist and active approach in deciding issues of medical negligence. The judge has greater freedom to scrutinise the reasoning behind an expert opinion, in much the same way as judges undertake this task in other areas of professional negligence such as in solicitors' negligence cases (31). Outside the context of medical negligence, the courts have had no difficulty with the notion that commonly adopted practices may themselves be negligent (32).

\section{LIABILITY IN THE MEDICAL FIELD \\ The Marinovich case in Australia}

The case of $B-v$-Marinovich (33), heard before Riley $\mathbf{J}$ of the Northern Territory Supreme Court, reflects the more independent position Australian courts have taken when deciding issues of medical negligence. In Marinovich the defendant psychiatrist was found negligent for failing to warn a patient of the addictive nature of certain tranquilliser and anti-depressant medications. The plaintiff's reliance on the medication fostered a relationship of dependence with the psychiatrist, which later led to sexual intercourse. The plaintiff also experienced serious withdrawal symptoms when she had completed the course of medication. The plaintiff claimed that on frequent occasions she had asked her psychiatrist whether there were any side effects associated with taking the prescribed drugs and whether the drugs were addictive. The defendant assured her that no side effects would be experienced and that the warnings of drug dependence, which were found on the labels of the medications, were placed there by the manufacturers to "protect themselves". The plaintiff later sued the psychiatrist for medical negligence.

\section{The finding in B - v- Marinovich}

The Court found that the psychiatrist did not inform the plaintiff of the side effects and dangers associated with the drug regime he prescribed. The plaintiff was not informed of the true nature of the drugs. She was not told of the ways in which the medication was psychologically and physiologically addictive. The patient was not given the opportunity to consider and choose a different approach. The judge considered that had the plaintiff been so advised, she would have chosen a different course of treatment. The medical evidence showed that there was an alternative and 
preferable course of treatment, which was accepted by the judge. Further, the Court held that the doctor encouraged the growing dependence of the patient by adopting the regime of pharmacological treatment and by fostering an inappropriately close personal relationship with his patient. The Court was of the view that, because of the doctor/patient relationship that existed between the two parties, a duty of care was cast on the defendant to inform the plaintiff of the risks involved in taking the prescribed medication.

The law therefore recognises that a doctor has a duty to warn a patient of the risks inherent in a proposed treatment. This duty is known as the doctrine of "informed consent". The medical profession should warn the patient of all "material" risks involved in a course of treatment. A material risk, according to the Australian High Court in Rogers - v- Whitaker, is one that a reasonable person, in the patient's position, would attach significance to. The decision in Marinovich suggests that it is the responsibility of the Court to reach an independent view, as to what constitutes a "material" risk, and not rely on accepted medical opinion.

The House of Lords, however, in the Bolam decision, appeared to leave the determination of a legal duty to inform of a "material" risk to the judgment of doctors. Yet this decision is subject to criticism. The question of to what extent a patient should be warned before consenting cannot be answered by reference exclusively to medical practice, as the patient has a right to be informed of inherent risks. In short, the medical profession cannot be a judge in its own cause. This criticism was reflected in Lord Scarman's dissenting judgement in Bolam. His Lordship concluded that there was room in English law for a legal duty to warn a patient of the risks inherent in a proposed treatment: should such a duty exist, its proper legal place could be considered as an aspect of the duty of care owed by the doctor to his patient.

\section{RECENT CASE LAW ON THE STANDARD OF CARE}

However, recent cases have suggested that there are situations where the courts will have regard to medical practice when determining the relevant standard of care. For example, the courts have tended to adopt a more lenient standard of care when considering the situation of elective surgery. A New South Wales Court of Appeal decision (34) indicates that the Court will, in fact, refer to current medical practices when adjudicating on whether a medical practitioner has satisfied the relevant standard of care when undertaking elective procedures. For example, in Tan -v-Benkovic (35), the Court held that:
The medical profession is best positioned to set its own standards as to appropriate professional practices in regard to what some would regard as elective procedures paid for later...Courts should not rush into areas in which subjective professional judgements predominate...(36)

In Tan $-v$-Benkovic the plaintiff sued the defendant because of "tightness, facial asymmetry and lines on her lips" (37) following plastic surgery. The defendant surgeon promised the plaintiff that the operation would make her look "twenty years younger" (38). In determining whether there was a breach of duty, the New South Wales Court of Appeal (39) questioned whether there was a "contumelious disregard of a doctor's duty to provide adequate care" (40). It was held that the defendant surgeon's "inducements and blandishments" did not amount to a "disregard for the doctor-plaintiff relationship" (41).

In the Tan case, the Court of Appeal appeared to assume a more lenient standard of care than the one adopted in Marinovich's case. It was held that Rogers $-v$-Whitaker did not require the surgeon to inform the plaintiff of all risks associated with the proposed operation. Further, while the plaintiff was undoubtedly "upset, vexed and depressed about the determinantal side-effects of the operation" (42) this did not amount to a breach of the doctor's standard of care. A similar approach was again adopted by the New South Wales Court of Appeal in Hunter Area South -v-Marchlewski (43).

On the other hand, the later decision of Presland $-v$ Hunter Area Health Service (44) has again highlighted the independent role of the Court in determining the appropriate standard of care without regard to medical practice or convention. The decision would appear to confirm the approach in Marinovich. In Presland, the defendant medical service discharged the plaintiff from its care since it was believed that the patient was not suffering any mental or psychiatric disorder. The plaintiff subsequent killed his brother's fiancée. The plaintiff was found to be suffering from psychosis. The New South Wales Court of Appeal held that the Hunter Area Health Service should have diagnosed the plaintiff's mental illness and reasonably foreseen that physical injury would have resulted following his discharge from the health service. The decision again emphasised the important role the Court will play in determining whether the defendant satisfied the relevant standard of care.

\section{THE DUTY TO WARN OF RISKS INVOLVED IN TREATMENT}

This raises the further concern as to how much information the doctor is required to impart to his or her 
patient? It is arguable that the medical practitioner is in the best position to assess what information a patient should receive. In view of both Rogers $-v$-Whitaker and $B-v$ - Marinovich, it appears that a higher, or more exacting, duty is imposed upon a medical practitioner under Australian law to inform the patient of a material risk, as compared to the approach of English law.

Criticism, however, has been raised in relation to the medical profession's ability to communicate effectively and to warn patients of the risks involved in treatment. A paper delivered at the 4 th annual conference of the Australian Institute of Health, Law and Ethics in July 1999 recorded that there were a number of perceived communication limitations pervasive in the medical profession and concluded that:

to communicate effectively; to act promptly to protect patients from poor practice; to be open about risks and variations in performance; and to admit to the errors that they are an everyday occurrence in judgment-based clinical decisionmaking (45).

With the imposition of a higher but undefined standard of care requiring medical practitioners to warn of every conceivable risk in a procedure, the question needs to be raised as to whether this will lead towards defensive medicine. Professor Jones (46) considers that this argument flies in the face of common sense and experience, which suggests that private sector defendants (solicitors, accountants, surveyors, etc) would need a sharp prod from the law of tort in order to achieve acceptable levels of competence. Jones's view has been reinforced by the recent House of Lords decision in Arthur J S Hall -v-Simons (47) where the Court conducted a thorough review of arguments for and against the abolition of advocates' immunity. One such argument in favour of retaining immunity was that advocates were more likely to act defensively, to the detriment of the overriding duty owed to the court in favour of their own position. That argument could not be supported as there was no evidence to suggest that advocates would act defensively contrary to their duties owed to the court and client.

\section{CONCLUSION}

The legal boundaries to the ethical standards in the legal profession are found in a fiduciary relationship, which encompasses every aspect of the lawyer-client relationship. That duty is particularly high, and understandably so, where the relationship is underpinned by one of trust and confidence. It has long been accepted that the lawyer-client relationship is a fiduciary one, principally to protect beneficiaries' fiduciary interests. Because the medical practitioner rarely has financial dealings with a patient, the courts have traditionally limited the scope of fiduciary relationship away from 'personal interests'. But with the rising standard expected of all professionals, especially so with medical practitioners, why should the fiduciary duty be limited? It is surely a relationship of trust and confidence, even within the constraints of the limited time that doctors are able to spend with patients. There may be fiduciary difficulties - for example, the situation of a white doctor and Aboriginal patient in both remote and urban parts of Australia - but this points to the need for greater awareness and enhanced training to deal with different patients.

This paper has explored the indicia giving rise to a fiduciary duty and now suggests that these concepts can be developed in the Australian common law to produce a new standard for cases such as $B-v$-Marinovich. The principle of fiduciary duties, as developed in Marinovich's case, also has implications for such increasingly important issues as access to medical records, and the use of a patient's genetic information. These concerns will be the focus of attention in our second, related paper

\section{REFERENCES}

1. Chief Justice Paul de Jersey "Recent Developments in Australian Negligence Law: Implications for the Insurance Industry", Insurance Council of Australia State Conference, Sheraton Hotel, Brisbane, May 23, 2003, 5. De Jersey notes the "increasingly plaintiff-friendly state in which negligence law is finding itself". His Honour points to the resultant 22 percent rise in insurance premiums in the 2001-2002 financial year: de Jersey, Insurance Council of Australia State Conference, Sheraton Hotel, Brisbane, May 23, 2003, 5. He supports the recommendations in the Federal Government's so-called "Ipp Report" which calls for a tightening of the law of negligence, in favour of defendants and away from plaintiffs.

2. (1999) NTSC 127.

3 Sidaway -v- Bethlem Royal Hospital Governors, per Lord Scarman, (1985) 1 AC 871

4. Norberg -v- Wynrib (1992) DLR 4th 449 per McLachlin J.

5. See Dorsett, S., 'Aspassin v The Queen in Right of Canada: Reexamining the Source of the Crown's Fiduciary Obligation to Indigenous Peoples' Aboriginal Law Bulletin, 78: 7, 1996.

6. Breen -v- Williams (1995-1996) per Dawson and Toohey JJ.

7. Breen -v- Williams (1995-1996) HCA 186 CLR 71 at 89.

8 Breen -v- Williams (1995-1996) HCA 186 CLR 71 at 89.

9 See Mabo -v- Queensland (No 2)(1992) 175 CLR 1 at 203. See also the imposition of a fiduciary duty in cases of mistaken payment of money: Chase Manhattan Bank -v- Israel-British Bank (1981) 1 CH 105.

10 Sidaway -v- Board of Governors of Bethlem Royal Hospital (1985) 1 AC 871 per Lord Scarman.

11. Breen -v- Williams (1995-1996) HCA 186 CLR 71 per Gummow J.

12. This was considered by the final report of the Taskforce on Sexual Abuse of Patients (25 November 1991) p11.

13. Paul Michalik, "Doctors' Fiduciary Duties" , Journal of Law and Medicine, 6: 172; 1998.

14. Breen -v- Williams (1996) 186 CLR 71 per Brennan CJ at p82.

15. Frame -v- Smith (187) $42 \operatorname{DLR}(4$ th) 81 at 104, per Wilson. J, and other non-pecuniary interests.

16. Re Gibson 369 NW 2d 466 (1985). 
17. Re Gibson 369 NW 2d 466 at 476 (1985).

18. Norberg -v- Wynrib (1992) 92 DLR (4th) 449 at 499.

19. Norberg -v- Wynrib (1992) 92 DLR (4th) 449 at 499 . In Canada, the law of fiduciary duties is more highly developed in the area of indigenous rights.

20. Norberg v. Wynrib (1992) 92 DLR (4th) 449 at 499.

21 (1999) NTSC 127

22. Rogers -v- Whitaker (1992) 175 CLR per Mason CJ.

23 Sidaway -v- Governors of Bethlem Royal Hospital (1985) AC 877 at 893, per Lord Diplock.

24. Gover -v- South Australia (1985) 39 SASR 543, at 551.

25. Bolam -v- Friern Hopsital Management Committee (1957) 1 WLR 582 at 586.

26. Molam -v- Friern Hospital Management Committee (1957) 1 WLR 582 at 586.

27. Canterbury -v- Spence (18) (1972) 464 F2d 772.

28. Reibl -v- Hughes (3) (1980) 114 DLR (3d) at 13.

29. (1992) 175 CLR 479.

30. Naxakis -v- Western General Hospital (1999) HCA 22; see also Rosenberg -v- Percival (2001) HCA 18 (5 April 2001).

31. Barbara Hocking and Stewart Muirhead "Warning, Warning, Warning - All Doctors!", PN, 16: 31; 2000.
32. Edward Wong Finance Co Limited -v- Johnson, Stokes \& Masters (1984) AC 296.

33. (1999) NTSC 127.

34. See Tan -v- Benkovic (2000) NSWCA 295 .

35. (2000) NSWCA 295.

36. (2000) NSWCA 295 at para. [31].

37 (2000) NSWCA 295 at para. [12].

38. (2000) NSWCA 295 at para. [6].

39. This test was also adopted in Droga v. Coluzzi (2000) NSWCA 1081; Blackwell v. AAA (1997) 1 VR 182 and Grincelis -vHouse (2000) 201 CLR 321.

40. (2000) NSWCA 295 at para. [7].

41. (2000) NSWCA 295 at para. [47].

42. (2000) NSWCA 295 at para. [31].

43. (2000) 51 NSWLR 268.

44. (2003) NSWSC 754.

45. See Jones, M "Fault, Negligence and the Standard of Care: A Conceptual Enquiry into Medical Critiques of Medical Litigation", Journal of Law and Medicine, (8): 68; 1999.

46. Jones M: "Liability for Psychiatric Patients: Setting the Boundaries", PN, 16: 45; 2000.

47. (1999) 3 WLR 873 per Lord Hoffman.

Dr. Barbara Hocking BA, LLB, LLM, PhD is a senior lecturer in the Faculty of Law of Queensland University of Technology in Brisbane, Australia. Stewart Muirhead LLB, is Master of Laws candidate at Queensland University of Technology in Brisbane, Australia. Scott Guy BA, LLB, is a PhD candidate at Queensland University of Technology in Brisbane, Australia. 